\title{
WOMEN OF AMERICAN CHAMBER MUSIC
}

\author{
Laena Grace Batchelder
}




\section{PROLOGUE}

This section will explain how I chose this project, which combines my loves of chamber music and feminism. First, I came to the decision to put on a full chamber recital since playing in chamber groups is my favorite thing to do. Soon, my friends agreed to perform with me. My friends are all fellow TCU performance majors, with whom I had performed in various chamber groups during my time as an undergraduate.

Next, I had to choose repertoire. At the time, I was learning about several American composers, including several women, in my Music History III class. I soon fell in love with Jennifer Higdon's music. I already knew her orchestral piece, blue cathedral, and through my research, I discovered her gorgeous quartet, An Exaltation of Larks. I began to consider the idea of programming only American female composers.

Before this project, I had been thinking about women's issues even more than usual. I took a Sex, Gender, and Culture anthropology course the previous semester and went to the Women's March in downtown Fort Worth in January 2018. My final decision to program only female composers came after I looked at my list of all the pieces I have ever played-solo, chamber, and orchestra. It had exactly one piece by a female composer-Amy Beach's Romance. After learning about more and more talented female composers in music history classes, I was upset to discover that I had gone fourteen years without playing any of them.

I listened to as many quartets as I could find by living American female composers including Julia Wolfe, Joan Tower, Gabriela Lena Frank, and Margaret Brouwer. Many of these were atonal, which I was not interested in performing. At last, I came across Death Valley Junction by Missy Mazzoli. Death Valley Junction is modern-sounding but reminded me of popular rock music that I enjoy. Finally, I chose Beach's Violin Sonata as the third piece on my recital since she is the most famous American female composer. 


\section{VIDEOS OF THE PERFORMANCE}

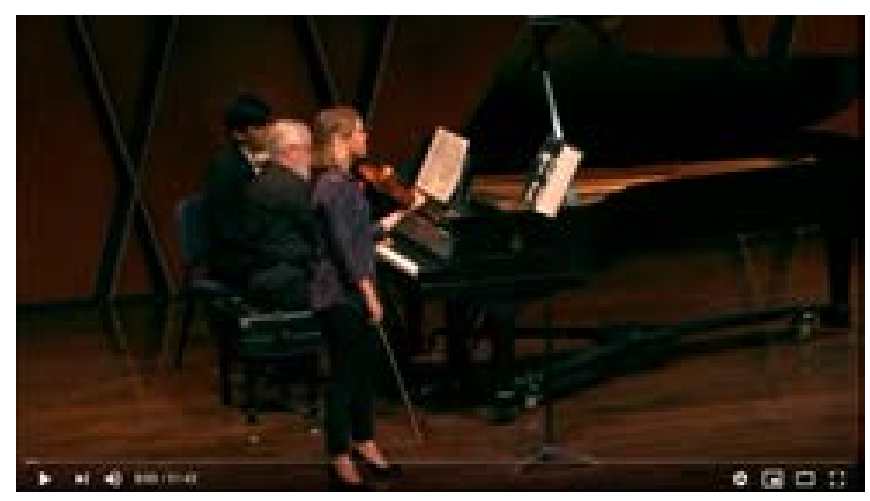

Amy Beach Violin Sonata

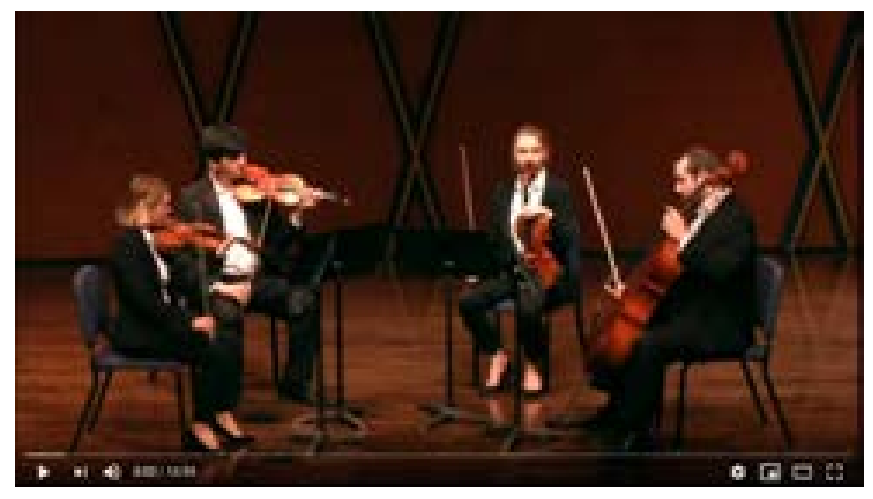

Missy Mazzoli Death Valley Junction

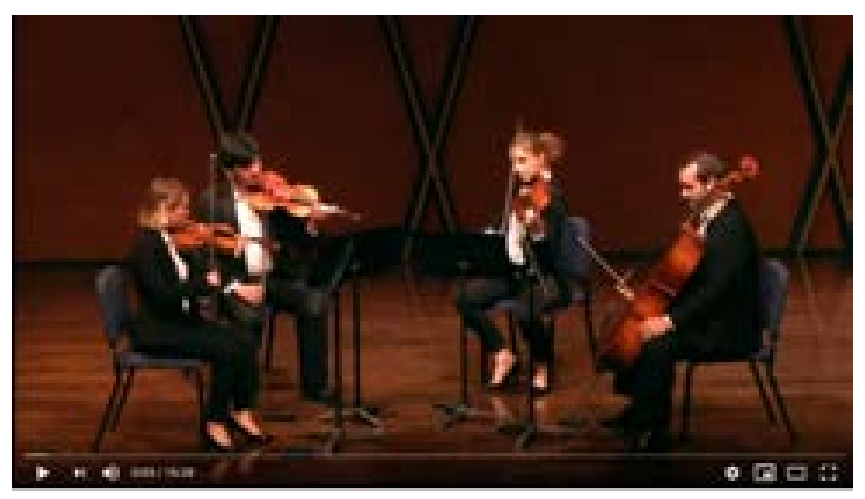

Jennifer Higdon An Exaltation of Larks 


\title{
ICU
}

SCHOOL OF MUSIC

Presents

\section{WOMEN OF AMERICAN CHAMBER MUSIC UPROAR STRING QUARTET}

\author{
Laena Batchelder, violin \\ Manuel Ordóñez, violin \\ Ashley Santore, viola \\ Manuel Papale, cello
}

FEATURING LAENA BATCHELDER, VIOLIN AND EDWARD NEWMAN, PIANO

February 20, 2019

7:00 pm

PepsiCo Recital Hall

\section{PROGRAM}

VIOLIN SONATA IN A MINOR, OP. 34 (1896)

Amy Beach

(1867-1944)

Allegro moderato

Scherzo: Molto vivace

Largo con dolore

Allegro con fuoco

DEATH VALLEY JUNCTION (2010)

Missy Mazzoli

(b. 1980)

AN EXALTATION OF LARKS (2005)

This recital is given in partial fulfillment of the requirements for a

Departmental Honors Thesis.

Ms. Batchelder is a student of Dr. Elisabeth Adkins.

The use of recording equipment or taking photographs is prohibited. Please silence all electronic devices including watches, pagers and phones. 


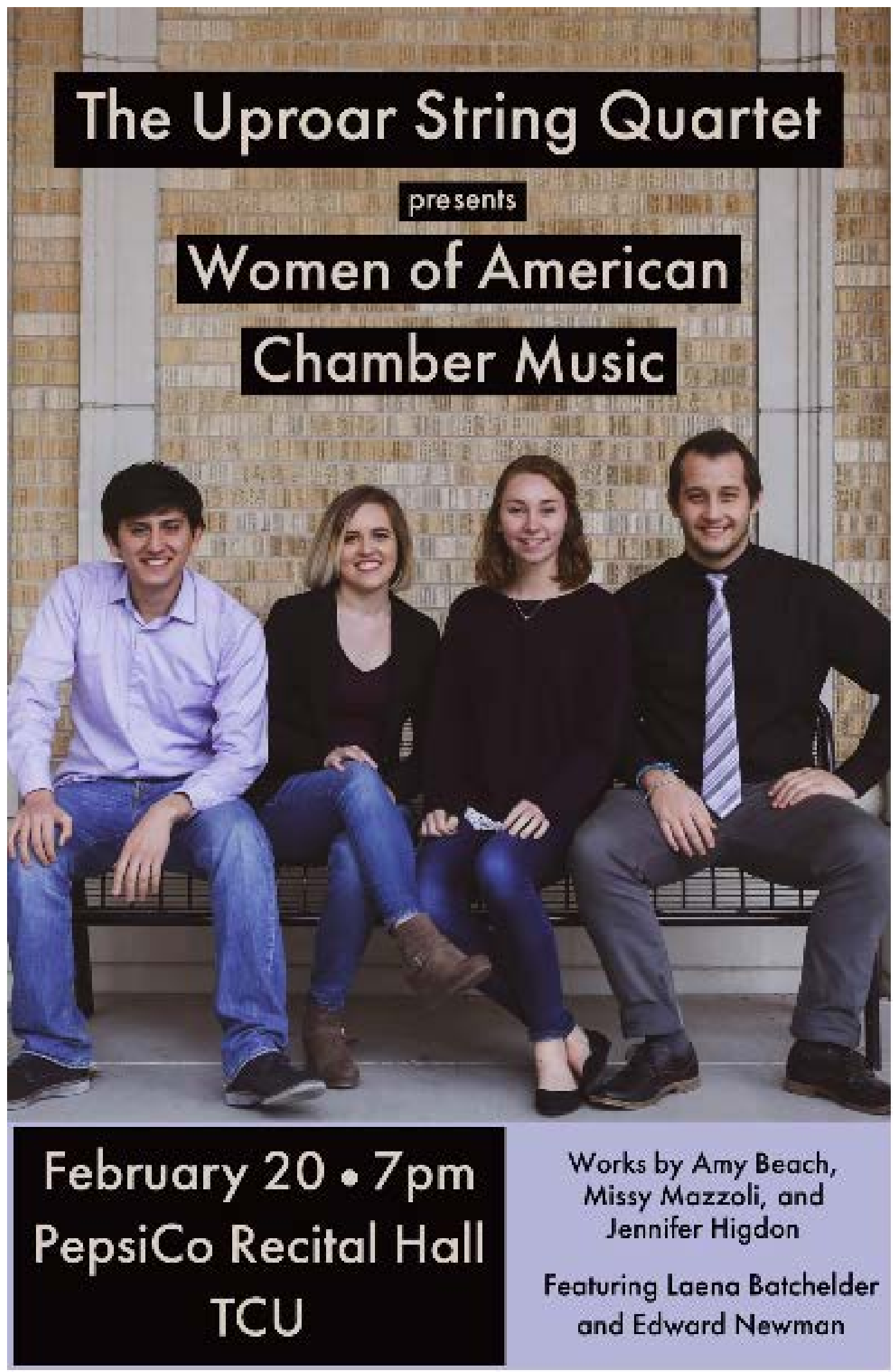




\section{WOMEN OF AMERICAN CHAMBER MUSIC}

Women are still underrepresented in classical music.

Some progress has been made recently.
In 1918, Louis C. Elson wrote in Woman in Music,

It is reasonable to believe that with the freedom that is accorded the woman-composer among us, with the numerous great conservatories here opening wide their doors to women and offering them the most thorough instruction, America may yet bring forth a woman-composer of the magnitude of Mozart, Chopin, or Haydn.

Even earlier, in 1901, the Baltimore Symphony Orchestra played the "Women in Music Grand Concert," programmed with only works by female composers living at the time. With this information, one might assume that after a century, music by women would be performed at every concert, especially in America. However, progress in the classical music world is slow. According to a study done by Ricky O'Bannon on the Baltimore Symphony Orchestra website, only 1.3 percent of pieces played by American orchestras in the 2016-17 season were composed by women. Of the pieces written by living composers that orchestras performed that season, only 10.3 percent were written by women, and the top nine mostperformed living composers were all male (although Jennifer Higdon had placed third the two previous concert seasons). A concert filled with works by women (like this one) is still quite rare and is often considered a novelty.

Recently, some progress has been made. New practices like blind auditions have helped to offset gender inequality (though large disparities still exist in some instruments). Four women have won the Pulitzer Prize in Music in the 2010s. For the 2018-19 season, Missy Mazzoli and Jeanine Tesori became the first women to be commissioned by the Metropolitan Opera, which had previously performed only two works by female composers-in 1903 and 2016. 
But we must actively support women in classical music.

"Infinitefacets of the female human experience to render."

In the 19th century, women mostly played music in private, but some became teachers and soloists.
This progress is still excruciatingly slow. Mazzoli herself said in an interview with National Sawdust Log,

I thought when I started my undergrad that by the time I got to be 37 years old, things would have dramatically changed. I just assumed that that would have happened. And it didn't. So now I think that maybe there's a potential for the change that I've wanted for the last 17 years.

We cannot assume things will get better on their own. We must program more works by women. We must encourage female composers throughout their careers. As Sarah Kirkland Snider said in a NewMusicBox article about her struggles with gender in her field of composition, "We've got a lot of lost time to make up for, and infinite facets of the female human experience to render." This recital renders one small facet by programming three chamber works by diverse American women.

\section{A BRIEF HISTORY OF AMERICAN WOMEN IN CLASSICAL MUSIC}

In 19th-century America, middle- and upper-class women were expected to learn music, along with sewing, drawing, dancing, and etiquette, according to Karin Pendle's book, Women \& Music: A History. This instruction was limited to singing and playing piano, harp, guitar, and later violin. Women were discouraged from making any kind of career out of music. But many became music teachers, and eventually, several became prominent soloists. Teresa Carreño and Camilla Urso were foreign-born piano and violin soloists, respectively, who performed extensively in the United States in the second half of the 19th century. Later, Illinois native Maud Powell rose to prominence as a violinist performing the American premieres of several famous concertos by Bruch, Lalo, Sibelius, Tchaikovsky, and others as well as introducing works by American composers like Amy Beach. 
Orchestral jobs were not available for women until the 1940s.

Women have performed in chamber groups since 1878.

Composing was considered a male field, but women were included in the Second New England School in the late 19th century.
Breaking into the orchestral world was a slower process. Women could join the few all-female orchestras but were not allowed into major orchestras (with a few exceptions) until as late as the 1940s, when World War II created openings for them.

Chamber music was another option. The Eichberg Quartette gave the first performance by an all-female string quartet in 1878. According to Christine Amber in her book Unsung: A History of Women in American Music, more and more women played in chamber groups through the 1920s, but women nearly disappeared from the stage both as soloists and chamber musicians in the "30s and '40s. Finally, women began to appear in prominent chamber groups in the 1960s and '70s such as the Cleveland Quartet and the Primavera Quartet. The Lark Quartet is a contemporary allfemale quartet that formed in 1985.

For most of history, composing was considered a pursuit that necessitated so-called male genius. Women were not given the educational opportunities or financial support necessary to succeed in this difficult field. A few women composed in early America, but most of their output was parlor songs that were sung in private settings. However, the Second New England School, a group of influential American composers in the late 19th century, included several female composers: Clara Kathleen Rogers, Helen Hopekirk, Margaret Lang, and Amy Beach. Lang's Dramatic Overture became the first work by a woman played by a major American orchestra, and Beach's Gaelic Symphony was the first symphony to have that same honor. These composers (and many female composers since) faced conflicting reviews in which critics judged their work to be either too feminine-emotional and spontaneous and therefore unworthy of real respect-or as masculine- denigrating femininity and all other female composers in comparison. Male composers, in contrast, rarely face reviews that mention their gender in any way. 
A few women composers were successful in the 20th century.

Amy Beach is the most famous female American composer.

Amy was a child prodigy pianist.
Several women composers were successful in the 20th century. Mary Howe and Marion Bauer were both American composers with similar impressionistic styles during the early 1900 s and studied with Nadia Boulanger, the famous French composition teacher. Florence Price was another notable female composer during this time whose nationalist music was successful despite her gender and African American race. The mid-century brought experimental female composers who delved into dissonance and serialism like Ruth Crawford Seeger, Vivian Fine, Louise Talma, and later Joan Tower. Many women in the second half of the 20th century created electroacoustic and electronic music, performance art, and avantgarde music. In 1983, Ellen Taaffe Zwilich became the first woman to win the Pulitzer Prize for Music for her Symphony No. 1, followed by Shulamit Ran for her Symphony in 1990. Zwilich, Ran, and other female composers like Julia Wolfe and Jennifer Higdon have had more public success since then, but they continue to be judged by their gender and not solely by their musical merit.

\section{AMY BEACH (1867-1944), VIOLIN SONATA IN A MINOR, OP. 34 (1896}

\section{0 minutes}

Amy Marcy Cheney Beach is the most celebrated female American composer. She appears first on a Google search for "female American composers," and Adrienne Fried Block's biography, Amy Beach, Passionate Victorian: The Life and Works of an American Composer, 1867-1944, appears quickly in library databases with the same vague search terms. Sadly, even though she is well-known, her works are rarely performed today.

Amy Cheney was born into a musical family and breathed music from the very beginning. She could harmonize to songs at the age of two and begged to play the piano. However, her mother disliked the idea of having a child prodigy for a daughter. Becoming a professional musician was against 
Amy married

Dr. H. H. A.

Beach who limited her performing but encouraged her composing.

Beach had several successful compositions including her Gaelic symphony.

Beach premiered her Violin Sonata in Boston. the feminine ideals of modesty and piety. Amy desperately wanted to play piano and was finally allowed to learn at age four, though her mother limited her practice time. Amy had perfect pitch, synesthesia, and began composing in her head. She was performing by age seven but was never allowed to leave Boston to perform or study.

Amy's piano playing and composing continued to blossom even under her mother's strict limits. In 1883, she published her first composition and had a successful debut as a piano soloist. Only two years later, however, she married Dr. Henry Harris Aubrey Beach, a man older than her father, and was passed from her mother's control to his. Dr. Beach severely limited Amy's performing but encouraged her composing. Amy learned to compose on her own with only books and scores as teachers because it was thought that women's creativity would be too easily crushed by a male teacher. As a married woman, her compositions now bore the name "Mrs. H. H. A. Beach." She said she was "pleased to bear" this name in her social and professional life.

Beach's compositions were very successful during her lifetime. She wrote her Romance for violinist Maud Powell, and they premiered it together at the 1893 World's Fair in Chicago. Her Gaelic Symphony was a nationalist work including real Gaelic folk tunes. Though the reviews for the symphony were generally quite positive, they often concentrated in finding masculine or feminine qualities in the work. Right after finishing the symphony, Beach wrote her Violin Sonata in A minor, her first large-scale chamber work, between March 11 and June 6, 1896.

Beach premiered her sonata with violinist Franz Kniesel on January 4, 1897, in Association Hall in Boston, receiving generally positive reviews. Pianist Teresa Carreño premiered the sonata in Europe with Carl Halir in Berlin in 1899. This performance was quite a success, and Beach later dedicated her piano concerto to Carreño. The famous violinist, Eugène Ysaÿe, also played the sonata in Paris in 1900 with Raoul Pugno. They supposedly did not know the work was by an American woman. 
Later, she played her popular sonata in Europe.

The sonata is a typical lateRomantic work.

\section{Allegro moderato \\ II. Scherzo: Molto vivace}

III. Largo con dolore

IV. Allegro con fuoco

Beach was conservative but inspired many future female composers.
After Beach's husband and mother died, she finally went on a European tour, and her first two performances included her sonata. The third recital included the sonata along with works by Bach, Beethoven, and Brahms - "the four Bs." The Violin Sonata is one of Beach's most popular pieces and was performed dozens of times during her lifetime.

Beach's Violin Sonata is fairly typical of a late-Romantic sonata and draws inspiration from composers such as Brahms, Grieg, and Franck. The passionate first movement is in sonata form with a highly chromatic development section. Beach uses thick textures and complex rhythms like hemiolas. She extensively develops the opening theme of this movement throughout the entire piece.

The second movement is a Scherzo and Trio in 2/4 with a folk-like, American-sounding theme perhaps inspired by Dvorák. It includes close imitation between the violin and piano and a long pedal tone on a low $G$ in the violin during the trio.

The slow, lyrical third movement is the most expressive including much dissonance and Wagnerian infinite melodies. Beach's experience with vocal writing is apparent in this movement. Biographer Block writes, "Urgency and romantic longing are written into the ever-present forward movement toward a resolution of dissonance that comes only with the last note."

The finale is also in sonata form, beginning with a sweeping introduction. The movement breaks into a fugue in the development section. After the recapitulation, Beach ends the piece in the parallel major achieving "resolution and transcendence" which she often did as she believed in music's power for moral redemption.

After hearing the strife, longing, pride, and passion in the piece, one might imagine that Beach was working out her struggles with her limitations as a woman under her husband's control. However, she wrote that she loved her husband and felt that her work was not judged according to her sex (though clearly it was). Beach was traditional in every way except her music-making. Though she was conservative 
Missy Mazzoli writes indieclassical operas.

She cofounded the Luna Composition Lab to mentor young female composers.

Death Valley Junction depicts a town in California and the woman who performed one-woman shows in the opera house there. herself, Beach "became an emblem for women's rights" according to a 2017 New York Times article by William Robin. Amy Beach became the model for future female composers, though arguably none have yet surpassed her level of influence.

\section{MISSY MAZZOLI (b. 1980), DEATH VALLEY JUNCTION (2010) 10 minutes}

Missy Mazzoli is the youngest, most actively feminist composer on the program. Her music can be described as indie-classical and combines elements of popular and contemporary classical music. She has several successful operas to her name which address thought-provoking themes. Her first opera, Songs from the Uproar, inspired the Uproar String Quartet's name. She also performs on keyboard with her band, Victoire, an electro-acoustic band dedicated to playing her music. In an interview with San Francisco Classical Voice, she said, "My mission is to connect with people. The purpose of creating music is to feel less alone, to create a community around the work to express something that can't be expressed in words."

Mazzoli often talks about the difficulties of women in the world of composition. In a New York Times article, she explained that men are given opportunities based on potential while women must already be proven-an impossibility if they never get a first opportunity. Mazzoli does more than raise awareness. In 2016, she co-founded the Luna Composition Lab based in New York which provides mentorship to young female and non-binary composers. This organization helps provide those first opportunities for girls.

In addition to her operas, Mazzoli has written many chamber works, including the single-movement quartet, Death Valley Junction. It was premiered on June 19, 2010, by Santa Fe New Music at the New Mexico History Museum. Her own program notes from publisher G. Schirmer, Inc. describe the piece well: 
The piece includes extended techniques like harmonics and glissandos.

Death Valley Junction is both inherently American and inherently female.
Death Valley Junction is a sonic depiction of the town of the same name, a strange and isolated place on the border of California and Nevada. The "town" is home to three people and consists of a café, a hotel, and a fully functional opera house. Death Valley Junction is dedicated to Marta Becket, the woman who resurrected and repaired the crumbling opera house in the late 1960s and performed one-woman shows there every week until her retirement last year at age 86. The piece begins with a sparse, edgy texture-the harsh desert landscape-and collapses into a wild and buoyant dance. Marta Becket once compared herself to the single yellow flower that is able to, against all odds, flourish in the desert. This piece attempts to depict some of her exuberant energy and unstoppable optimism and is dedicated to her.

According to a New York Times article by Richard Sandomir, Marta Becket was a New York ballerina and Broadway dancer who bought the opera house on a whim. She performed her one-woman show there for yearssometimes with no one in the audience and sometimes with a full crowd.

The piece begins with sliding harmonics underneath a harsh viola solo. Mazzoli gives very specific instructions to slowly switch between playing sul ponticello-over the bridge —and sul tasto-over the fingerboard. As she described, the middle of the piece depicts Marta Becket's dance with almost constant sixteenth notes, melodies switching between all the instruments, and sweeping glissandos. The piece descends into almost complete chaos before returning to the harmonic desert of the beginningthis time with a cadenza-like cello solo.

Death Valley Junction is truly American, depicting a tiny town in the West. Mazzoli's newest opera, Proving Up, will continue to explore American themes like the American Dream. Death Valley Junction is also whole-heartedly female-written by an innovative woman about another remarkable woman. Mazzoli's music is highly creative yet approachable, and her ideas and outreach may clinch her role as the future of women in American classical music. 
Jennifer Higdon is the most successful female composer of the 21st century.

She was not exposed to classical music until high school.

Higdon's composing style is intuitive and American.

\section{JENNIFER HIGDON (b. 1962), AN EXAITATION OF LARKS (2005)}

\author{
16 minutes
}

Jennifer Higdon may be the Amy Beach of the 21st

century. She has won a Pulitzer Prize and two Grammy Awards, and according to her website, her orchestral tone poem blue cathedral is one of the most performed contemporary works, with over 600 performances since its premiere in 2000. She is one of the few modern selfsupporting composers and writes only on commission. According to Christina Reitz's book, Jennifer Higdon: Composing in Color, Higdon does not believe her gender or lesbian orientation has any impact on her success or her music. This fact is also reminiscent of Beach's beliefs.

On the other hand, Higdon's childhood was very different from Beach's. While Beach was immersed in classical music from birth, Higdon had no experience with it until high school. She grew up with artsy, countercultural parents in Tennessee and listened to bluegrass, country, and rockespecially the Beatles. Her first experience playing music was as a percussionist in her high school marching band at age fourteen. Soon she grew interested in learning the flute and taught herself. She was first exposed to classical music at this time, listening to recordings from the library. As a flute performance major in college, she began to compose and later received several degrees in composition. Now she teaches a limited number of students at the Curtis Institute of Music in addition to composing.

Higdon has described her composition process as "intuitive." She does not think about form or key centers while composing and hears music as lines rather than harmonies. Her music often uses major chords, ostinatos, lyrical solos, unifying rhythmic motives, and colorful orchestration. Her music is also known for its liberal use of perfect fifths which 
An Exaltation

of Larks

depicts the

chaos and

beauty of

flying, singing

larks.

Both Higdon and Mazzoli believe music is about communicating to their audiences. gives it an American sound. Additionally, according to an NPR interview with conductor Marin Alsop, Higdon believes "her combination of melody and rhythm reflect our spoken language."

Though Higdon is best known for her Neo-Romantic orchestral works, she has also written many chamber works for a wide range of ensembles. An Exaltation of Larks is a single-movement quartet commissioned by the Tokyo String Quartet in 2005. Coincidentally, the only professional recording of the piece was done by the above-mentioned Lark Quartet. Higdon's own thoughts from the program notes on her website vividly introduce the piece:

The first time someone told me that a collection of Larks is called an "Exaltation," I immediately thought, "What a sound an exaltation of larks must make!" This prompted my imagination to run wild in a composerly fashion, thinking of thousands of birds flying and singing wildly, with extraordinary energy and intensity. Not to mention the wonderful play on words that is implied with "exaltation." How to capture the beauty of the idea of exalting and singing? A string quartet seemed perfect!

Trills, harmonics, complex rhythms, and high virtuosic melodies conjure images of the flying, singing larks depicted in the piece. The piece is sometimes chaotic but never loses its beauty. According to Reitz, Higdon's music is best described as sectional, but An Exaltation of Larks' form is similar to traditional sonata form with a slow introduction, exposition, development, and recapitulation. The development slows the pace after the energetic exposition, highlighting the first violin and cello. The section slows even further for beautifully complex interlocking melodies in all four instruments. The recapitulation brings back the wildness with only a brief return to the slow section right before the triumphant coda.

Higdon's idea about the purpose of music is very similar to Mazzoli's. For her, music is "about communicating with something undefinable within musicians and audience 
members." Even though Higdon may not believe her gender affects her career, her feminine experience allows her to communicate different undefinable ideas to audiences, allowing some of them to better connect with her music. She will inspire more girls to follow in her footsteps who will write more music to explore the "infinite facets of the female human experience."

-Laena Batchelder, 2019 


\section{EPILOGUE}

Reflecting on our preparation and performance, I found learning Beach's Violin Sonata to be an enlightening experience. Mr. Edward Newman, the husband of my violin professor Dr. Elisabeth Adkins, is a professional pianist, but he had never played the sonata before. So, we had the opportunity to learn the piece together. I think Mr. Newman went on a journey from doubting Beach's compositional ability to being as enraged as I am that such a wonderful piece is not played more often. When we began rehearsing, he criticized the piece for being indulgent, but eventually he realized that it is the height of lateRomantic emotion. I enjoyed shaping the dynamics, articulation, and timing with him to express that emotion.

The Uproar String Quartet rehearsed at least an hour and a half each week for over a semester to prepare for this recital. We had several coachings with my violin professor, Dr. Adkins, as well as one each with the viola and cello professors at TCU, Dr. Misha Galagonov and Professor Christine Lamprea. My colleagues and I learned much from playing these two contemporary pieces. They were each quite difficult in different ways. Mazzoli's Death Valley Junction was hard to put together and includes extended techniques like ponticello. We wrote many cues of the other players' parts in our music to learn when to play at the right time and often rehearsed with the metronome. By the time of the performance, we knew what everyone else was playing (almost) at all times. Even if we got off, we had made so many mistakes in rehearsal that we always knew how to get back together.

Higdon's An Exaltation of Larks was quite difficult technically with complex rhythms and tricky intonation. I think I practiced this piece on my own more than any other chamber piece in my life. An Exaltation of Larks was also more difficult than the average quartet to put together, but we worked quite a bit on blend and tone quality as well. Learning these difficult pieces made us all better chamber musicians. They taught us many new ways to rehearse chamber music which we hope to use with more traditional pieces in the future.

I hope to apply what I learned from preparing for this recital to many future projects. I plan to program works by contemporary, minority, and female composers as much as I can. We cannot assume progress will occur naturally. As composer Sarah Kirkland Snider said, "We've got a lot of lost time to make up for, and infinite facets of the female human experience to render." 